\title{
SEMINARIO
}

\section{Similarities between skull fragment VM-0 from Orce (Spain) and the Homo erectus holotype from trinil (Java)}

\author{
Bienvenido Martínez Navarro \\ Museo de Prehistoria y Paleontología “J. Gibert”, 18858 Orce, Granada, Spain.
}

In 1982, cranial fragment VM-0 was found at the Venta Micena site in the province of Granada, southern Spain. The fragment measures between 7.5 and $9 \mathrm{~cm}$ in diameter, and comprises part of the two parietal bones and the upper occipitalis squama. In anatomical orientation, the fragment occupies the area of the obelion.

The curvature of this skull fragment, length of the sagittal suture, form of the suture at its most posterior end (S4), and the angle formed by this suture and the lambdoid sutures, suggested that the fossil belonged to a primitive member of the genus Homo. It was found in association with an older Lower Pleistocene faunal assemblage. The fossil was reported by Gibert et al. (1983) on the basis of external anatomical features only, as the internal surface was covered by tightly cemented calcareous gangue that was difficult to remove.

Cleaning of the endocranium at the Museo Arqueológico in Barcelona required more than six months' work. The team who had originally discovered the fossil then travelled to the Musée de l'Homme in Paris to perform comparative studies.

The inner surface of fossil VM-0, belonging to a juvenile individual, showed well-developed digital impressions and a crest leading in a sagittal direction on the occipital bone, neither features of which had been described in classical works of human anatomy. On the basis of these features, the Parisian laboratory suggested that the fossil might have belonged to an equid of 3 or 4 months of age.

This difference of opinions led Agustí \& Moyà-Solà (1987) to publish a brief note contradicting their earlier claims and assigning the fossil to an equid, on the basis of the digital impressions and the occipital crest. These investigators also described a hypothetical coronal suture, which they judged to be present and partially obliterated.

Radiographic images of the fossil indicated that signs of the coronal suture were in fact caused by desquamations of the inner cortical bone, and thus obviated this argument. However, the other two features had no precedent in the human anatomical literature, and required further comparative analysis. In Barcelona, Campillo (1989) compared the fossil with modern human occipital bones, and concluded that the two features noted above fell within the range of normal anatomical variation. He also observed crests and digital impressions in skull bones from modern children. In Sabadell, Gibert et al. (1989) determined that
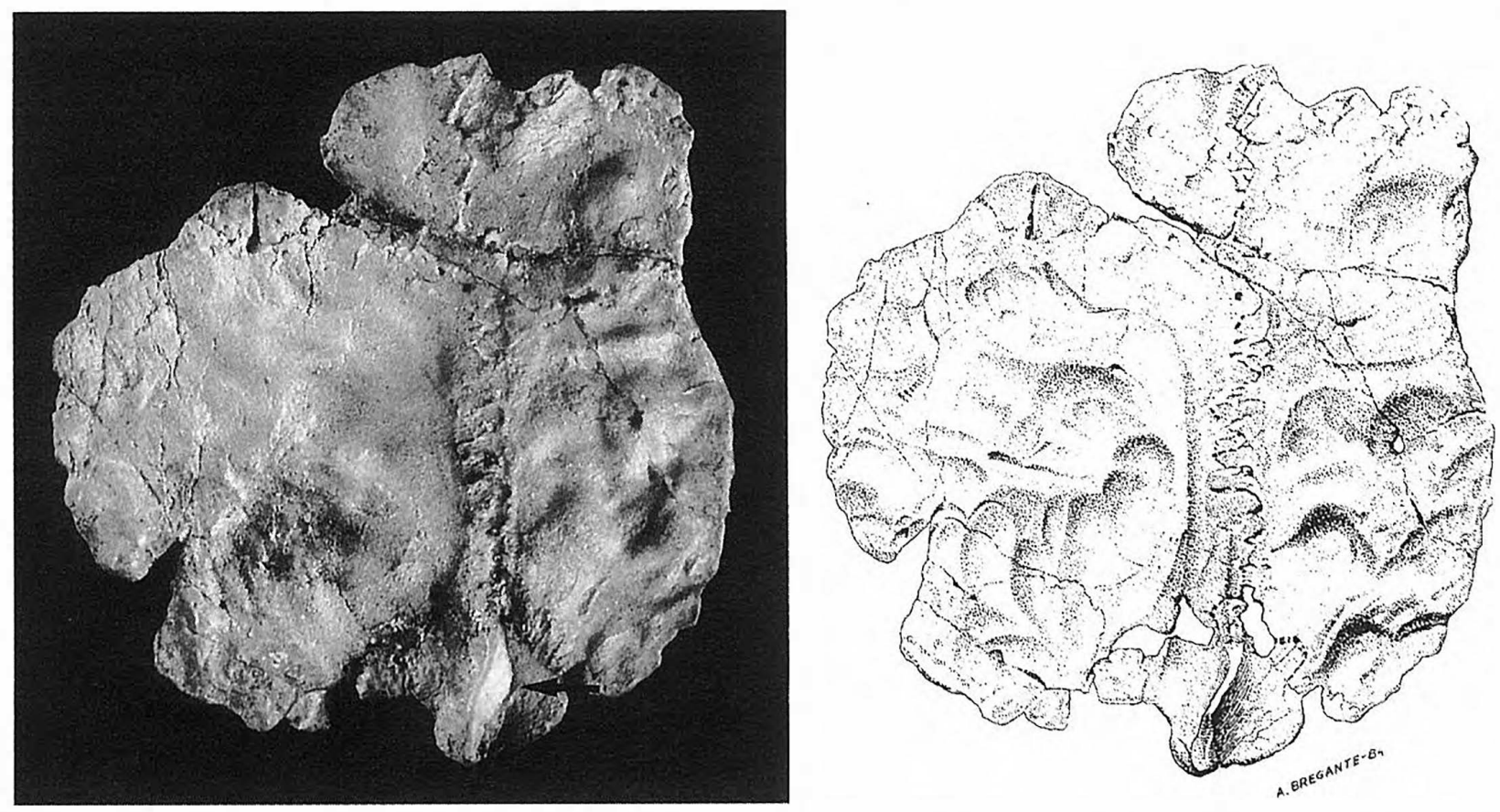

Figure 1. Inner surface of the skull fragment of the VM-0 from Venta Micena. The arrow point out the famous occipital crest of this piece. Actual size. [The free hand drawing is reprint from Campillo (1989)]. 

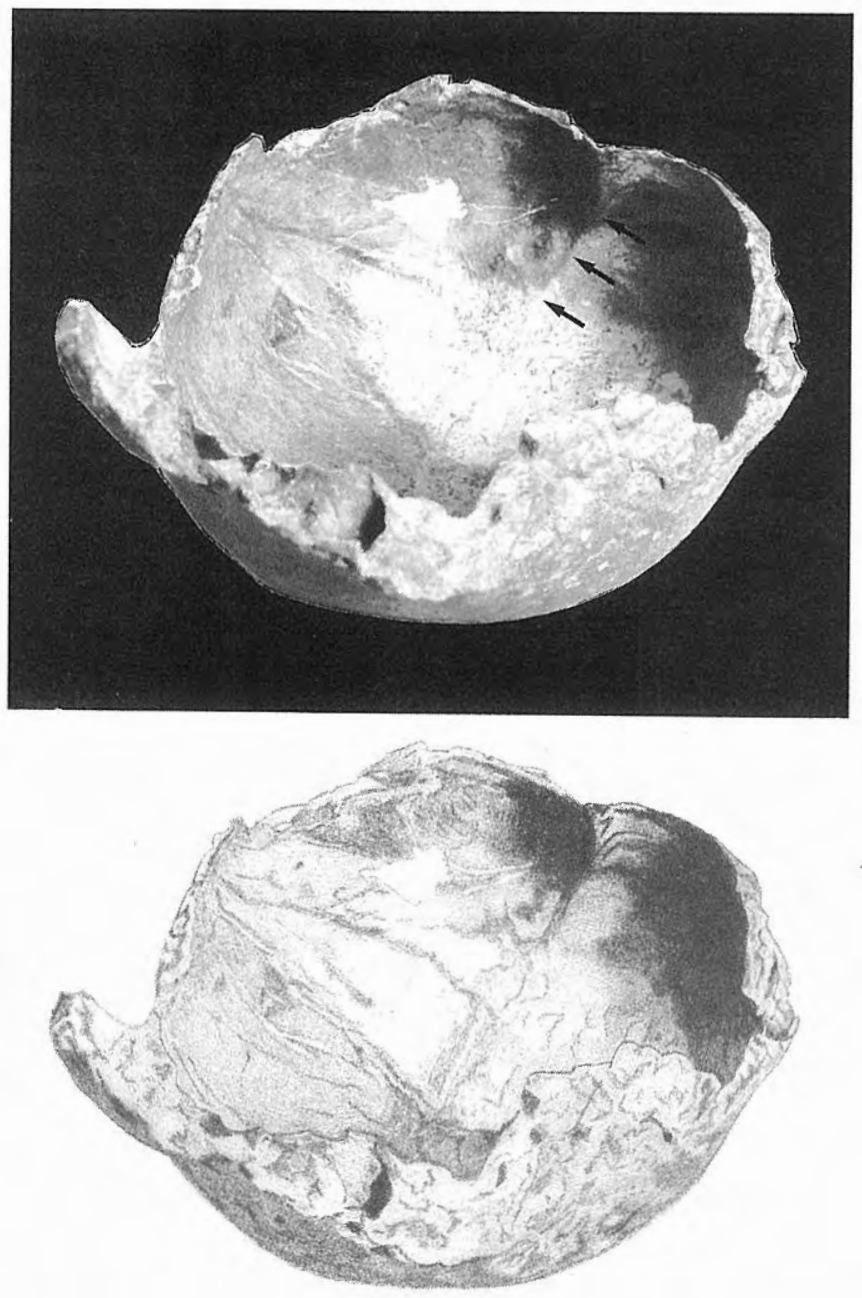

Figure 2. Inner surface of the Trinil skull (Homo erectus holotype) from Java. The arrows point out the occipital crest running sagitally. The aproximative escale is $45 \%$.

the VM-0 cranial fragment was different from all other families of mammals.

Other methodological approaches to resolve the identity of the fossil have provided more credible evidence in favor of a hominid assignation. In Granada, Borja et al. (1992) and Borja (1995) recovered and characterized fossil human proteins in the fossil with polyspecific and monoclonal antibodies. Using the same methods, they recently recovered equid proteins from fossil bones assigned on the basis of conventional paleontological studies to an equid. These results were corroborated independently in San Francisco by Lowenstein with radioimmunoassays. In Málaga, Gibert \& Palmqvist (1995) used fractal geometric analysis to rule out attribution of the fossil to an equid, on the basis of the sinuosities of the sagittal and lambdoid sutures. They found that the fractal dimension of the sutures was within the range of variability for humans.

Fossil VM-0 has now been compared directly with conclusively identified human fossils from sites dated to ages close to that proposed for Venta Micena. Cranium KNM ER-3733 from Koobi Fora (Kenya), attributed to
Homo ergaster, and the holotype of Homo erectus from Trinil (Java) both display a crest running sagitally on the occipital squama, similar to the structure present in skull fragment VM-O from Orce. In KNM ER-3733, the crest is rounded rather than laminar; in the $H$. erectus holotype the crest is well-delimited, although not as laminar as in the Orce fossil (Figures 1 and 2), probably because the Asian fossil belonged to an adult rather than to a juvenile specimen.

Widely different investigative techniques employed independently now provide forceful evidence that the VM0 cranial fragment belonged to a primitive hominid that probably died before reaching full maturity.

\section{Acknowledgements}

Appreciation is expressed to the Dirección General de Investigación Científica y Técnica (Spanish Ministry of Science and Education) for financial support through Project PB94-1222-C02-02. I thank Dr. J. de Vos, curator of the Duvois Collection at the Nationaal Natuuhistorisch Museum of The Netherlands in Leiden, for allowing me to study the collection, to M. van Englenen of the Rijks Universiteit Leiden, who took the photograph of the Trinil skull and to L. Sanz Sampelayo, who drew it. I also thank Dr. M.G. Leakey and Dr. E. Mbua, who arranged permission through the Secretariate of the President's Office of the Republic of Kenya to examine human fossils deposited at the National Museum of Kenya.

\section{References}

Agustí, J. y Moyà-Solà, S. 1987. Sobre la identidad del fragmento craneal atribuído a Homo sp. en Venta Micena (Orce, Granada). Estudios Geológicos, 45, 535-538.

Borja, C. 1995. Detección y caracterización de proteínas fósiles mediante técnicas inmunes. Tesis Doctoral, Universidad de Granada, 330 pp.

Borja, C., García-Pacheco, J.M., Ramírez-López, J.P. y GarcíaOlivares, E. 1992. Cuantificación y caracterización de la albúmina fósil del cráneo de Orce. In: Proyecto Orce-Cueva Victoria (1988-1992): Presencia humana en el Pleistoceno inferior de Granada y Murcia (Coord. J. Gibert). Museo de Prehistoria J. Gibert, Ayuntamiento de Orce (Granada), 415423.

Campillo, D. 1989. Estudio del Hombre de Orce. In: Los restos humanos de Orce y Cueva Victoria (Eds. J. Gibert, C. Campillo y E. García-Olivares). Instituto Paleontología "M. Crusafont"-Diputación de Barcelona, 109-186.

Gibert, J. \& Palmqvist, P. 1995. Fractal analysis of the Orce skull sutures. Journal of Human Evolution, 28, 561-575.

Gibert, J., Agustí, J. y Moyà-Solà, S. 1983. Presencia de Homo sp. en el yacimiento del Pleistoceno inferior de Venta Micena (Orce, Granada). Paleontologia i Evolució, Publicación especial, 12 pp.

Gibert, J., Campillo, D., Ribot, F., Ferrández, C., MartínezNavarro, B. \& Caporicci, R. 1989. Anatomical study: Comparison of the hominid cranial fragment from Venta Micena (Orce, Spain) with fossil and extant mammals. Human Evolution, 4, 283-305. 